\title{
An Evaluation of Sub-Skills (Vocabulary, Grammar and Pronunciation) in the Grade 9 English Textbook of Afghan Secondary Schools
}

\author{
Rahmatullah Katawazai , Mustafa Haidari, Sandaran SC
}

\begin{abstract}
English language is a part of the school's curriculum in all levels in Afghanistan as a foreign language. Despite it being including for decades, very little research has been done in regard to the quality and evaluation of the ELT English textbooks. The current study investigates and evaluates English Language Sub-skills of the secondary school textbook "Grade 9" to evaluate the effectiveness of the materials for the teaching and learning of the subskills. The Eclectic Checklist of Demir \& Ertas (2014) has been selected for evaluating the selected English textbook. The findings indicate that the selected textbook lacks contextualized usage of vocabulary, systematic representation and sufficient explanations of grammatical structures, and appropriate usage of pronunciation activities. Furthermore, the findings indicate that the textbook needs improvements in developing and presenting the sub-skills of English language appropriately, particularly grammar and pronunciation. These findings will be helpful to policy makers and ELT textbooks developers of Afghanistan to represent the contextualized and appropriate usage of the English Language sub-skills in upcoming versions of ELT textbooks.
\end{abstract}

Keywords: ELT Textbook Evaluation, Grade 9 EFL Textbook, Afghanistan

\section{INTRODUCTION}

Teaching and learning are two interrelated aspects of gaining knowledge. These aspects involve three main participants that can make the process of gaining knowledge easy: instructor, learner and teaching materials.

Teaching materials are one of the most important constituents of any language program (McDonough \& Shaw, 2003; Richards 2001) and they further stated that they provide second language learners with adequate input to practice and are mostly considered as reliable sources of ideas for inexperienced teachers to plan and teach lessons in their classrooms [1], [2]. For this reason, teaching materials, especially textbooks, can play a significant role in the process of teaching and learning. Besides, textbooks should be organized in way that is easy to use, not only for the instructors, but for the learners as well. It means that the structure of teaching materials is one of the vital features that is sometimes ignored by material developers or curriculum designers.In English language teaching, normally, the teaching materials are divided based on skills, i.e. listening,

Revised Version Manuscript Received on April 19, 2019.

Rahmatullah Katawazai Faculty of Education, Department of English, Kandahar University, 3801, Kandahar, Afghanistan

Mustafa Haidari Faculty of Education, Department of English, Kandahar University, 3801, Kandahar, Afghanistan

Sandaran, SC Language Academy, Universiti Teknologi Malaysia, 81310, Johor Bahru, Johor, Malaysia speaking, reading and writing. In order for a language to be mastered by learners, materials developers need to contextualize the four main skills in the EL textbooks. Within that, sub-skills are as important to be contextualized as the main skills of a language because they are the building blocks for the four main skills. Vocabulary, Grammar and Pronunciation are the sub-Skills of main skills for language learning.

For example, for learners to be able to master a language, they need to acquire a certain level of vocabulary. Hoshino stated that vocabulary is the basis of language; thus, we can never underestimate its importance in learning a target language [3]. Faerch \& Phillipson stated that the knowledge of vocabulary in EFL can give the ability to the learners to not only comprehend words, but to activate them as well. Furthermore, grammar is another sub-skill of language that the learners need to acquire. They need a certain level of the structures in a language. Thus, they need to learn grammatical structures and use the list of vocabulary words not only in oral communications, but in written texts as well $[4$, p. 100] Richards \& Reppen [5] stated that Grammar can be viewed both as knowledge and as ability. When viewed as knowledge, the focus is on rules for sentence formation and when viewed as ability, the focus is on how grammar is used as a resource in the creation of spoken and written texts. Within that, pronunciation is another vital sub-skill that learners need to master. Harmer [6, p. 248] identifies the importance of pronunciation instruction as "Pronunciation teaching not only makes students aware of different sounds and some features, but can also improve their speaking immeasurably". Ketabi [7, p. 187] mentioned that the importance of pronunciation, must be the focus of second language teachers as it is instrumental in enabling learners to produce intelligible speech for effective communication in a globalized world.

As the sub-skills are important language elements for the learners to master a second language, the purpose of the current study is to investigate how the sub-skills are presented in "Grade 9" English Textbook of Afghan Secondary Schools. There have been numerous researches on evaluating ELT textbooks, but in the Afghan context, this is still missing. To the knowledge of the researchers, not much research has been conducted on EL practices in the Afghan context. The study aims to: 
i. evaluate the suitability of the materials for the teaching of sub-skills (i.e. vocabulary, grammar, pronunciation) in the Grade 9 English Language textbook used in Afghan secondary schools

\section{LITERATURE REVIEW}

Sub-skills are as the building blocks for the main skills of learning and mastering a language. It means that in order for a learner to master a language, ELT textbooks developers need to contextualize them all for the language learners for them to be successful learners. This means that the sub-skills of vocabulary, grammar and pronunciation help learners to not only understand a language, but enable them to be able to communicate with others as well.

\section{Vocabulary and Language Learning}

Harmon, Wood, Hedrick, Vintinner \& Willeford [8] defined that vocabulary learning is a continual process of encountering new words in meaningful and comprehensible contexts. Jose $[9$, p. 8] further explains that "a strong base of vocabulary knowledge is indispensable for fostering the language skills which are the four pillars of English language". Young-Davy [10] stated that improved vocabulary use leads to a feeling of success, in contrast, a lack of vocabulary impairs learners at all levels of academic endeavors and undermines even the most diligent learners. He further explains that there are there steps that that can help learners improve their vocabulary such as selection, definition, exposure and use.

Enriched vocabulary can not only help learners to understand meanings from the contexts, but it can prepare them to use appropriate words in appropriate speaking situation communicatively. According to Schmitt [11], determination strategies are used when students discover the meaning of a new word without using the experience of another person. In this strategy, students try to guess and discover the meaning of the new words with the help of context, structural knowledge and reference material. That means students find the meaning of the words on their own. Schmitt [11] notes that another way of discovering a new meaning is to ask the unknown words to others by using social strategies. Baskin, Iscan, Karagoz \& Birol [12] mentioned that metacognitive strategies are to decide which words are worth learning, plan consciously, and find the most effective learning method. They recommend that in this type of strategy, learners control and evaluate their own learning, this plays an important role in choosing a learning strategy because it is a positive reinforcement of progress, or they call it, a strategy change. Baskin, Iscan, Karagoz \& Birol [12] recommend metacognitive strategies that include planning, monitoring and evaluation and they believe that it provides a conscious overview of the language learning process.

\section{Grammar and Language Learning}

Ozturk [13] believes that grammar was the dominant teaching element in foreign language teaching until the beginning of the 20th century. It means that if we observe the classical language teaching methods, a particular attention was paid for including grammatical rules and based on these rules, various types of drills were designed in the instructional materials. For example, the Audio-lingual and Grammar-translation methods paid particular attention in integrating grammatical rules for language learners. Polat [14] identified that in most language classes, the necessity of grammar teaching and the ways to integrate it into foreign language learning is a crucial matter that many researchers have studied.

Ellis [15] considers the complexity of factors and variables in grammar instructions e.g. how grammar is and should be taught, implicit-explicit, inductive-deductive, integrated-isolated, whether or not knowledge of grammatical terminology enhances learning, whether grammar work is best handled through $\mathrm{L} 1$ or L2, etc. He, for example claims that implicit instructions and traditional forms of grammar teaching will enable the learners to gain some automatic self-check systems that will help them create grammatically accurate structures. Similarly, Lightbown [16] called grammar instructions a 'hook' for learners by which they could form a basis to build up their proficiency in producing utterances in English.

In summary, teaching grammatical rules and placing them in instructional materials appropriately has been focused not only in the classical methods of teaching, but also in more recent methods. For this reason, it has been recommended by language scholars to put grammatical rules, based on the needs of the students and the teaching skills of the teachers, as effectively as possible in order to help learners become independent and communicative users of a language.

\section{Pronunciation and Language Learning}

Pronunciation is another vital sub-skill of language learning that helps the learner to use vocabulary and grammatical rules communicatively. Pronunciation teaching in general has been shown to be mostly effective for the improvement of both segmental and suprasegmental features of English (Couper, 2003; Derwing, Munro, \& Wiebe, 1998; Kennedy \& Trofimovich, 2010; Neri, Mich, Gerosa, \& Giuliani, 2008; Saito, 2007; Saito \& Lyster, 2012) [17]-[22].

Derwing \& Munro [23] explain that most of the instructional materials and practices developed for L2 pronunciation tend to rely heavily on basic intuitive notions suggested by language teachers and researchers, rather than research-based evidence. As Celce-Murcia, Brinton, and Goodwin [24, p. 279] assert, "Perhaps more than any other aspect, pronunciation is the salient feature of our language competence. It is the lens through which we are viewed in each interaction we have". Furthermore, researchers have claimed that pronunciation is important for fluency as well as for effective communication.

\section{METHODOLOGY}

This study evaluates the sub-skills (vocabulary, grammar and pronunciation) in the "Grade 9" ELT textbook in Afghan Secondary Schools. All the textbooks of Afghan primary and secondary schools have been organized and published by the Ministry of Education after particular stages of revisions by 
various committees in the platform of the Ministry of Education of Afghanistan. The book has been composed and designed by the authors themselves. It consists of 16 units (170 pages). On the front page of the book, there are some images of religious, historical, and literary settings. In this inside of cover page, the National Anthem of Afghanistan is written in the National Language of Afghanistan (Pashto).

The Grade 9 English Textbook used in Afghan Secondary Schools is evaluated based on Demir \& Ertas' [25] Eclectic Checklist (Table 1.).

\section{Table 1.}

\begin{tabular}{ll}
\hline & Does the vocabulary load (i.e. the \\
& number of new words introduced \\
every lesson) seems to be found \\
reasonable for the students of that \\
level? (12) \\
Is there a good distribution (simple to \\
complex) of vocabulary load across \\
chapters and the whole book? (11) \\
Do the vocabulary exercises promote \\
internalization of previously and \\
newly introduced items? (13) \\
Are the new vocabulary words repeat \\
in subsequent lessons to reinforce their \\
meaning and use? (1) \\
Is the new vocabulary integrated in \\
varying contexts and situations? (14) \\
Are the grammar points presented with \\
brief and easy examples and \\
explanations? (15) \\
Is the Secondary function of new \\
structures for interaction and \\
communication? (14) \\
Do the structures gradually increase in \\
complexity to suit the growing reading \\
ability of students? (12) \\
Are the new structures presented \\
systematically and in a meaningful \\
context? (16) \\
Are the grammar points recycled in the \\
following units? (4) \\
Is there sufficient work on recognition \\
and production of stress patterns, \\
intonation and individual sounds? (17) \\
Are the pronunciation points repeated \\
and reinforced in subsequent lessons? \\
(13)
\end{tabular}
are shown in Table 1. above. A total of 12 questions are given, with 5 items respectively on the sub-skills of vocabulary and grammar and 2 items for pronunciation. Each item is evaluated based on the criteria of Positive, Neutral, and Negative.

The textbook consists of 16 units with the focus on language skills (e. g., Listening, Speaking, Reading, and Writing) and sub-skills (Vocabulary, Grammar, and Pronunciation). Four revision units have also been included in the book, i.e. after three units have been completed; there is one unit for the revision of the previous three units. For this reason, the revision units have been skipped in this study. Only the sub-skills of grammar, vocabulary and pronunciation are explored using the criteria of the selected checklist for
The items from the checklist used to evaluate the sub-skills

evaluation.

In order to evaluate the suitability of the materials provided for the teaching of the sub skills, the Eclectic Checklist by Demir \& Ertas is used. Montasser [26] explained that by employing a checklist, it would be then easier to establish comparison among diverse materials. Soori, Kafipour \& Soury [27] stated about the evaluation checklist that it is a list of criteria which can be used for the evaluation of the book, particularly, for teaching materials. Within, as they believe that teachers, researchers, or even students can evaluate the teaching and learning materials based on the criteria of the checklist. In this study, the researchers were the evaluators of the textbook.

\section{FINDINGS \& RESULTS}

The results based on the items in the checklist on the suitability of the materials provided in the textbook for the sub-skills of vocabulary, grammar and pronunciation are discussed in this section.

\section{Vocabulary}

The table below shows the evaluation of the sub-skill of vocabulary. The items are based on the criteria of positive, neutral and negative.

Table 2.

\begin{tabular}{|c|c|c|c|}
\hline Criteria & Positive & Neutral & Negative \\
\hline $\begin{array}{l}\text { Does the vocabulary } \\
\text { load (i.e. the number } \\
\text { of new words } \\
\text { introduced every } \\
\text { lesson) seems to be } \\
\text { found reasonable for } \\
\text { the students of that } \\
\text { level? (12) }\end{array}$ & $\checkmark$ & & \\
\hline $\begin{array}{l}\text { Is there a good } \\
\text { distribution (simple } \\
\text { to complex) of } \\
\text { vocabulary load } \\
\text { across chapters and } \\
\text { the whole book? } \\
(11)\end{array}$ & $\sqrt{ }$ & & \\
\hline $\begin{array}{l}\text { Do the vocabulary } \\
\text { exercises promote } \\
\text { internalization of } \\
\text { previously and } \\
\text { newly introduced } \\
\text { items? (13) }\end{array}$ & & & $\sqrt{ }$ \\
\hline $\begin{array}{l}\text { Are the new } \\
\text { vocabulary words } \\
\text { repeated in } \\
\text { subsequent lessons } \\
\text { to reinforce their } \\
\text { meaning and use? } \\
(1)\end{array}$ & & & $\checkmark$ \\
\hline
\end{tabular}

The first criterion of the checklist asks whether the vocabulary load is reasonable for the current level of the students. We have affirmed with a 'positive'. The total 
number of new words being introduced in Grade 9 are around 480, which are presented over 12 units. Thus, we can say that there is sufficient importance given to the teaching of the sub-skill of vocabulary in this textbook. The second criterion asks about the suitability of the vocabulary distribution across the chapters of the whole book. The response to this question is also 'positive'. It can be said that the number of new vocabulary introduced and distributed across each unit of the book related to the lessons is sufficient. The distribution of the vocabulary items from simple to complex is suitable for the level of the learners. For example, in Unit Two, page number (23), words such as 'Troupe and Gut' are included. Suitable distribution of the words is one of the strongest points of the selected book.

The next question asks if vocabulary exercises promote internalization of previously and newly introduced items. The answer to this question is negative, since the Grade- 9 book lacks exercises that promote both previous and newly introduced vocabulary. It can be said that all of the exercises are to practice new vocabulary only. However, although there is a revision unit after three units, not much focus is given to the recycling of vocabulary items introduced in the three units.

The answer to the question "Are the new vocabulary words repeated in subsequent lessons to reinforce their meaning and use?" is also negative. As it was stated before the words introduced in each unit of the book are not recycled and repeated in the subsequent new units. Furthermore, the revision chapter does not facilitate the recycling of vocabulary items to show the connection of the new vocabulary words with the previous ones. The answer to the last question of the checklist for vocabulary on whether the new vocabulary words are integrated in varying contexts and situations, is also negative. There are a fix number of situations for vocabulary in each unit. New words are not contextualized with different types of exercises. There are very few exercises for vocabulary and are taught in isolation. Stahl [28] cautions against mere repetition or drill of the words, and emphasizes that vocabulary instruction should provide students with opportunities to encounter words repeatedly and in a variety of contexts.

\section{Grammar}

The following table, shows the findings for the sub-skill of grammar. In general, it can be said that this sub-skill has been given more focus in the textbook.

Table 3.

\begin{tabular}{|l|c|c|c|}
\hline Criteria & Positive & Neutral & Negative \\
\hline Are the grammar & & $\checkmark$ & \\
points presented & & & \\
with brief and easy & & & \\
examples and & & & \\
explanations? (15) & & $\checkmark$ & \\
\hline Is the Secondary & & \\
function of new & & & \\
structures for & & & \\
interaction and & & & \\
communication? & & \\
(14) & & & \\
\hline
\end{tabular}

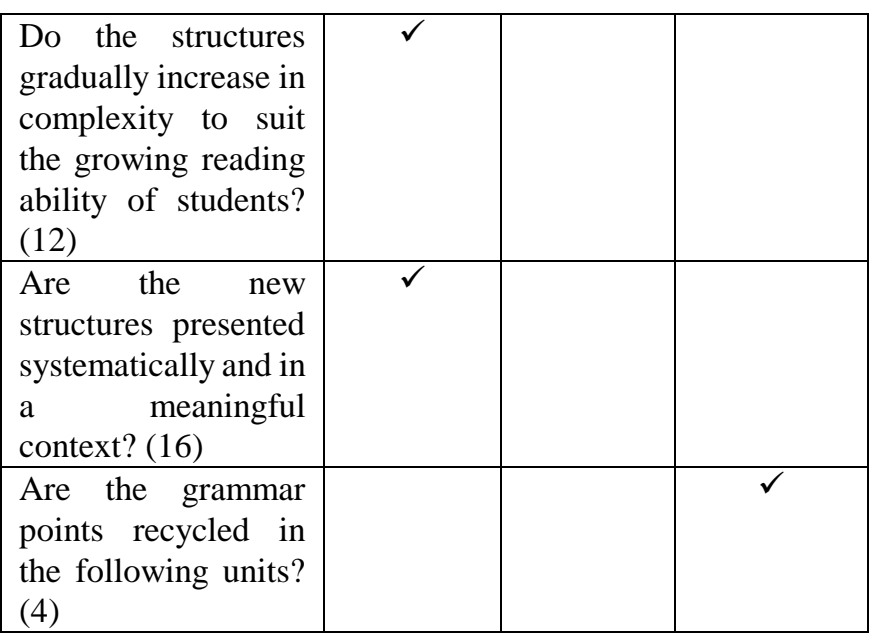

The answer to the first question "Are the grammar points presented with brief and easy examples and explanations?" is neutral. The term neutral expresses the meaning of being moderate. The textbook provides examples and exercises for practice grammar items but do not give explanations. Thus, it is up to the teacher to include the explanations. Chastain [29] posits that explanations are necessary when teaching grammar, the type of grammar explanation itself plays a significant role in determining its usefulness. The second question asks if the grammar items are taught for interaction and communication. The answer is neutral. The book provides exercises and mostly conversation activities which set the platform to use the structures by means of interaction and communication. But, there are no specific exercises in order to promote the interaction and communication aspect of the structures. The next question is on whether the grammar items are presented gradually from simple to complex structures. The answer is positive. The represented grammatical items in the book are sequenced from easy to complex. This element is present in all units of the textbook. For example, in the very beginning chapter (unit one) of the textbook, simple present tense has been placed and structures e.g. Conditional clauses, which are gradually more complicated are stated in upcoming units (unit three).

The fourth item of the checklist for grammar relates to the importance of new structures being presented systematically and in a meaningful context. Grammatical structures which have been placed in the book are systematically placed within suitable contexts. Structures have been placed meaningfully and related to the elements of the unit. The final question asks if the grammar points are recycled in the following units, and the answer is negative. Grammatical items taught are neither revised nor repeated in other units. For this reason, the textbook lacks to recycle the grammatical points of the previous unit in the following one.

\section{Pronunciation}

Pronunciation is the last sub-skill of the checklist which seems to be the weakest one among the three. The table indicates that materials and activities for the teaching of pronunciation are a weakness of the textbook.

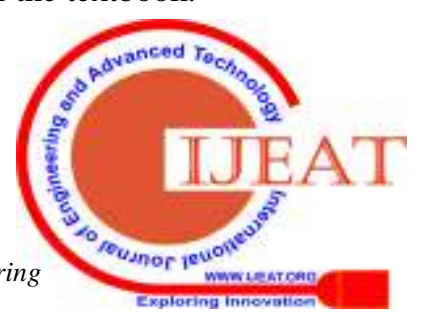


Table 4.

\begin{tabular}{|l|l|l|c|}
\hline Criteria & Positive & Neutral & Negative \\
\hline Is there sufficient & & & $\checkmark$ \\
work on recognition & & \\
and production of & & \\
stress patterns, & & \\
intonation and & & \\
individual sounds? & & \\
$(17)$ the & & & \\
\hline Are and & & \\
pronunciation points & & \\
repeated in & & \\
reinforced lessons? & & & \\
subsequent led \\
(13)
\end{tabular}

The first question is on whether there is sufficient work on recognition and production of stress patterns, intonation and individual sounds, and the answer is a negative response. No explanations or activities have been included on the teaching and learning of stress patterns or intonations. There is some focus on the teaching of individual sounds. Furthermore, there are no explanations or instructions for teachers or students on the sounds of the phonemes, this is a problem as Afghan students and even teachers may not be familiar with English phonetics or phonology. Shabani \& Ghasemian [30, p. 2] reaffirm that "Knowing the way of expressing and stating a sound or word is very important in English because to mispronounce a word may change the meaning of the word". The last question is on whether there are pronunciation items that are repeated and reinforced in subsequent lessons. Once again, the response is 'negative' as the materials for the teaching of pronunciation is minimal in the textbook. For this reason, it can be stated that the textbook lacks suitable representation of the pronunciation.

\section{V.DISCUSSION}

The study set out to locate the suitability of materials provided for the teaching of the sub-skills of vocabulary, grammar and pronunciation, in the Grade 9 English language textbook used in Afghan secondary schools. In general, it can be said that there the textbook is lacking in suitable materials for some elements of the teaching of the sub-skills. For the teaching of vocabulary, the book introduces a balanced vocabulary load according to the level of the students. It also has a good level of distribution of new words to be taught gradually from simple to complex words in all the units. However, one weakness of the textbook is in relation to internalization of new and previous vocabularies, subsequent repetition of previous vocabularies, and integration of vocabularies in a variety of contexts. The textbook fails to fulfil the selected criteria of the checklist. Thus, introducing new vocabulary without recycling their use in subsequent units and exercises is important for the learning of vocabulary. As stated by Stahl [28], repetitions of use of vocabulary are crucial and a lack of it means there is less retention of the words by the students.

For the sub-skill of grammar, the textbook has sufficient coverage of grammar items and the grammatical structures are presented from simple to complex. However, the textbook lacks explanations for the presented grammatical structures.
And importantly, grammatical items are not recycled or repeated in subsequent units. This is a weakness of the textbook.

Very little focus has been given for the sub-skill of pronunciation in the textbook. As the status of English is as a foreign language in Afghanistan, the teaching of pronunciation, an especially of the sounds, stress, phonemes, etc. should be prioritized. The textbook needs to include audio recordings of the sounds, and of a variety of speakers of English to expose both students and teachers to correct pronunciation of words. In terms of the materials for the teaching of pronunciation, the book needs more improvements to fulfill the standards of checklist.

\section{CONCLUSION}

The findings of the current study, based on Demir \& Ertas eclectic checklist, indicate that the ELT English Grade 9 textbook of Afghan Secondary school needs to be improved in terms of the materials provided for the teaching and learning of the sub-skills of vocabulary, grammar and pronunciation. The findings would help textbook developers and ELT language teachers see the need for the much needed improvements in the textbook for effective teaching and learning of the English Language specifically for the Afghan EFL context.

\section{REFERENCES}

1. McDonough J, Shaw C. Materials annd Methods in ELT. Malden: Blackwell. 2003.

2. Richards JC. Curriculum development in language teaching. Ernst Klett Sprachen; 2001.

3. Hoshino Y. The categorical facilitation effects on L2 vocabulary learning in a classroom setting. RELC Journal. 2010 Dec;41(3):301-12.

4. Færch, C., \& Phillipson, R. Learner language and language learning. Multilingual Matters Limited. (1984). (Vol. 14).

5. Richards JC, Reppen R. Towards a pedagogy of grammar instruction. RELC Journal. 2014 Apr;45(1):5-25.

6. Harmer J. The practice of English language teaching. Harlow: Pearson Longman,; 2007.

7. Ketabi S, Saeb F. Pronunciation teaching: Past and present. International Journal of Applied Linguistics and English Literature. 2015 Sep 1;4(5):182-9.

8. Harmon JM, Wood KD, Hedrick WB, Vintinner J, Willeford T. Interactive word walls: More than just reading the writing on the walls. Journal of Adolescent \& Adult Literacy. 2009 Feb;52(5):398-408.

9. Jose GR. Acquisition of Vocabulary by Dint of Unique Strategies: Indispensible for Fostering English Language Skills. Journal on English Language Teaching. 2015;5(2):7-18

10. Young-Davy B. Explicit Vocabulary Instruction. Ortesol Journal. 2014;31:26-32.

11. Schmitt N, McCarthy M. Vocabulary: Description, acquisition and pedagogy. Cambridge university press; 1997.

12. Baskin S, Iscan A, Karagoz B, Birol G. The Use of Vocabulary Learning Strategies in Teaching Turkish as a Second Language. Journal of education and practice. 2017;8(9):126-34. 
13. Öztürk BK. Evaluation of the Grammar Teaching Process by Using the Methods Used in Turkish Language Teaching as a Foreign Language: A Case Study. Universal Journal of Educational Research. 2018;6(2):278-88.

14. Polat M. Teachers' Attitudes towards Teaching English Grammar: A Scale Development Study. International Journal of Instruction. 2017 Oct;10(4):379-98.

15. Ellis R. Current issues in the teaching of grammar: An SLA perspective. TESOL quarterly. 2006 Mar;40(1):83-107.

16. Lightbown PM. What have we here? Some observations on the role of instruction in second language acquisition. Foreign/second language pedagogy research: A commemorative volume for Claus Faerch. 1991:197-212.

17. Couper $\mathrm{G}$. The value of an explicit pronunciation syllabus in ESOL teaching. 2003

18. Derwing TM, Munro MJ, Wiebe G. Evidence in favor of a broad framework for pronunciation instruction. Language learning. 1998 Sep;48(3):393-410.

19. Kennedy S, Trofimovich P. Language awareness and second language pronunciation: A classroom study. Language Awareness. 2010 Dec 3;19(3):171-85.

20. Neri A, Mich O, Gerosa M, Giuliani D. The effectiveness of computer assisted pronunciation training for foreign language learning by children. Computer Assisted Language Learning. 2008 Dec 1;21(5):393-408.

21. Saito K. The Influence of Explicit Phonetic Instruction on Pronunciation in EFL Settings: The Case of English Vowels and Japanese Learners of English. Linguistics Journal. 2007 Dec 1;2(3).

22. Saito K, Lyster R. Effects of form-focused instruction and corrective feedback on L2 pronunciation development of/I/by Japanese learners of English. Language Learning. 2012 Jun;62(2):595-633.

23. Derwing TM, Munro MJ. Second language accent and pronunciation teaching: A research-based approach. TESOL quarterly. 2005 Sep;39(3):379-97.

24. Brinton D, Celce-Murcia M, Goodwin JM. Teaching Pronunciation: A Course Book and Reference Guide. Ernst Klett Sprachen; 2010 Sep 6.

25. Demir Y, Ertas A. A suggested eclectic checklist for ELT coursebook evaluation. Reading. 2014 Sep 1;14(2).

26. AbdelWahab MM. Developing an English language textbook evaluative checklist. IOSR Journal of Research \& Method in Education. 2013 Mar;1(3):55-70.

27. Soori A, Kafipour R, Soury M. EFL textbook evaluation and graphic representation. European Journal of Social Sciences. 2011;26(3):481-93.

28. Stahl SA. Four problems with teaching word meanings. Teaching and learning vocabulary: Bringing research to practice. 2005 Mar 16:95-114.

29. Chastain K. Examining the role of grammar explanation, drills, and exercises in the development of communication skills. Hispania. 1987 Mar 1:160-6.

30. Shabani K, Ghasemian A. Teacher's personality type and techniques of teaching pronunciation. Cogent Education. 2017 Jan 1;4(1):1313560.

\section{AUTHORS PROFILE}

Rahmatullah Katawazai was born in the year 1991/March/21 in Paktika province of Afghanistan. He studied his primary and secondary studies in Yousuf Khail High School, located in his birthplace and after graduation from the school, he passed the Kankur exam and succeeded to the Kandahar University, Faculty of Education. He studied English Literature there and he was the top of his class. After his graduation, he was joined as an academic member of Kandahar University in the year 2014. He is currently the postgraduate student of TESL at Universiti Technologi Malaysia. Many of his articles have been published in one of the national languages of Afghanistan (Pashto) in the national magazines and newspapers. Within, he translated many articles in Pashto language and these articles have been published in the national journals and magazines of Afghanistan as well. Two of his research articles are published in the international journals.

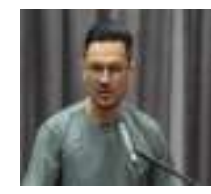

Mustafa Haidari was born in the year 1991/April/26 in Kandahar province of Afghanistan. He studied Ahmadshah Baba High School in Kandahar. After graduation from the high school, he passed the Kankur exam and succeeded to the Faculty of Education, Kandahar University. He studied English Literature there and successfully graduated from that faculty. After his graduation, he joined as an academic member of Kandahar University in the year 2014. He translated many article into the national languages of Afghanistan (Pashto \& Dari).

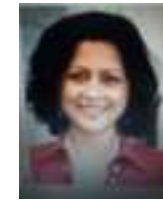

Sandaran, SC. (Ph.D), senior lecturer. Areas of interest: Critical Discourse Analysis, TESL, Service Learning, Engineering Texts. Language Academy, Faculty of Social Sciences and Humanities,UniversitiTeknologi Malaysia.Tel: +60167771364 E-mail: shanti@utm.my 